\title{
Chapter 5 \\ Integration of Recently Arrived Migrants in the Swiss Labour Market - Do the Reasons for Migration Matter?
}

\author{
Philippe Wanner
}

\subsection{Introduction}

Over the last three decades, Switzerland has observed huge changes in the structure of migratory flows (see Chap. 1). Although the country was already characterized by the arrival of groups of immigrants with various characteristics and levels of technical skills, a new trend in migration flows has emerged, with an increased proportion of highly skilled migrants being registered in the last 10 years (Wanner et al. 2016). In the framework of the so-called Migration-Mobility Nexus (see Chap. 1), this migration is largely explained by demand-led immigration provoked by a rapid transformation towards a more specialized economy and by a shortage of human resources in some high value-added sectors, such as IT services, health and specific financial sectors. Other factors, such as taxation, quality of work and business expansion in some branches, can also play an important role in the decision of highly skilled migrants to relocate (Mahroum 2000); these factors have also been observed in Switzerland. Finally, changes in the legislation concerning labour workers in relation to the ratification of bilateral agreements between Switzerland and the EU have accelerated the trend towards highly skilled immigration because it is now easier to hire EU workers.

This transformation of the flows has led to an increase in the average age of migrants, who increasingly frequently move in their thirties or even forties, often after the constitution of their families, resulting in a progressive increase in the proportion of family migrants since the $1970 \mathrm{~s} .{ }^{1}$ However, the preliminary results of the

\footnotetext{
${ }^{1}$ According to the Swiss State Secretariat for Migration, more than $30 \%$ of the migration to

P. Wanner $(\square)$

Institute of Demography and Socioeconomics IDESO, University of Geneva,

Geneva, Switzerland

nccr - on the move, Neuchâtel, Switzerland

e-mail: Philippe.Wanner@unige.ch
} 
Migration-Mobility Survey 2016 demonstrate that professional factors remain the main reason for migration, concerning almost two-thirds of migrants. The characteristics of immigration towards Switzerland are very complex, and the motives to immigrate are varied. For instance, almost one-third of those surveyed provide more than two reasons for their migration.

With the development of international migration, a considerable amount of research has been performed on the issue of structural integration, i.e., at school and in the labour market (for Switzerland, see for instance Liebig et al. (2012) and Fibbi et al. (2006)). Beyond measuring the level and occasionally the pace of integration, most of the research also identifies the individual factors, if any, that influence migrants' integration: for instance, educational background, country of origin, age, and family structure; or contextual factors such as integration policies, discrimination or stereotypes concerning some groups of migrants. One aspect that has thus far been poorly explored is how the reasons behind migration affect integration (Kofman 2004; Kofman and Raghuram 2005). The lack of studies on this topic is notably explained by the limited availability of appropriate data (Bevelander and Pendakur 2014). Surveys and population registers rarely contain information on both the reasons for migration and the status in the labour market. In general, researchers who consider this topic focus on one specific migrant group, most frequently asylum seekers or refugees (for instance, Rashid (2009) for Sweden and DeVoretz et al. (2004) for Canada), who are the most concerned with integration issues. The researchers do not adopt a comparative approach among migrants categorized according to their reasons for migration.

However, the level of integration and satisfaction in the labour market can differ according to the context in which migration has occurred. In particular, it is expected that the so-called "secondary migrants", "tied migrants" or "family migrants" have lower levels of integration into the labour market (Meares 2010) due to the time needed to find a job corresponding to their skills, a situation that is conducive to poor usage of the skills available (brain waste). A "tied" or "secondary migrant" is generally defined as an individual in a family that decided to move due to the employment status of his partner but who, if single, would have stayed (Cooke 2013). Tied migrants are usually women following their partners to a foreign country, although a recent study in the United States demonstrated that this phenomenon is not limited to women (Cooke 2013).

For the host country, it is important that secondary migrants can also access the labour market not only to realize their economic potential but also to contribute to their effective integration into the host society. It is also expected that their level of satisfaction with the migration is lower in the case of difficulties in accessing the labour market, which can also lead to different health-related issues.

It is in this context, using the Migration-Mobility Survey, that this paper aims at measuring the extent to which the reason for the migration affects the level of

Switzerland is today explained by family reunification. Although no data are available in the long term, one can state that this proportion is far higher than in the period of immigration of guest workers, between the end of World War II to 1970 approximately. 
integration into the labour market. We use four indicators to infer the position of migrants in the labour market and their level of satisfaction concerning the working conditions. We aim at assessing the effect of the reasons for migration on those indicators. We also aim at identifying which other individual migrant characteristics influence the level of integration into the labour market. The hypothesis tested in this chapter is that, after considering other confounding variables, the reason to migrate is significantly correlated with our indictors.

The one question in the survey documenting the reason for migration, which was self-declared by the respondents, makes it possible to test such a hypothesis. One can however observe that the decision to migrate is also increasingly diverse and complex to identify precisely, which can make it difficult to link the declared motive with the level of structural integration (Luthra et al. 2014).

\subsection{State of the Art}

As mentioned below, the situation of family migrants is rarely documented, in particular because of the focus on migration by men and its economical outcome (Webb 2015). In contrast, the level of integration in the labour market is not only one of the objectives of any immigration policy ${ }^{2}$ but also the topic of numerous studies in industrialized countries. The labour force participation of migrants, particularly those coming from southern countries, refers to different dimensions addressing national legislation (for instance referring to the recognition of foreign qualifications), the individual characteristics of migrants, or attitudes of employers, for instance in terms of discrimination practices (OECD and European Union 2015). Based on the literature, one can observe that immigrants, whatever the motive for migration, need time to integrate into the host labour market in a position that corresponds to their skills. Based on an analysis of immigrant earnings in different host countries, (Adsera and Chiswick 2007) show that approximately 18 years are necessary for immigrants to close the gap with natives in terms of wages, after considering confounding variables.

Poor skills in the local language are frequently mentioned as being among the individual factors hampering this integration into the labour market (Dustmann and Fabbri 2003). Conversely, social networks in the host country, social contacts with the host population, and a high level of education (Amuedo-Dorantes and De la Rica 2007) can accelerate the pace of integration into the labour market. Concerning education, one acquired in the host country is generally considered more useful for integration into the labour market than is the one acquired in the country of origin (Akresh 2008). Country of origin, age and household composition are other factors influencing the level of structural integration. Gender is also mentioned in studies as

\footnotetext{
${ }^{2}$ See for instance the action plan of the European Commission, https://ec.europa.eu/home-affairs/ what-we-do/policies/legal-migration/integration/action-plan-integration-third-country-nationals_ en. Accessed 29 Mai 2018.
} 
a factor influencing integration (Blau et al. 2011). The influence of the motives behind the decision to migrate is rarely considered in studies measuring the factors of integration, although such motives provide an understanding of the factors triggering the migration and therefore must be explored.

Migration theory is progressively addressing the increasing complexity of migration. In fact, rational theories based on the neoclassical approach, which links the mobility of individuals to wage differentials, has progressively diminished in importance and relevance as other, more sophisticated theories have emerged, for instance the new economics theory of migration (Harbison 1981; Stark 1991). In contrast to earlier theories, which stated that migration is an individual decision, the new approach suggests that the decision to migrate is made after considering different dimensions or potential effects that the choice can provoke not only for the migrant but also for his/her family. In our case, the decision to migrate in Switzerland is rarely an individual decision but increasingly a collective decision made within the family (Nauck and Settles 2001).

In the context of highly skilled migration, the personal motivations of the primary migrant (in particular, the one who has secured employment in the Swiss labour market) might collide with the personal expectations of the partner (or secondary migrant). This point is particularly true when - generally highly educated partners give up their current employment to accompany the primary migrant in the host country without having secured a job for the time of arrival. Occasionally, the partner is not ready to lose his/her situation and stays in the country of origin ("tied stayer", see Cooke (2013). However, the partner, a "tied migrant", often accepts being confronted with issues concerning his integration into the Swiss labour market.

Family migrants are usually confronted with greater difficulties than are primary migrants in integrating professionally (see for instance in Canada Man (2004). The difficulties are amplified by the fact that highly skilled migration generally occurs when one is older than is true of low-skilled migration, at a period in life when education has been completed, professional skills are precisely defined and professional flexibility is relatively low compared with the situation of younger people. This situation can contribute to making it more difficult for partners of primary migrants to reintegrate into the labour market in a position similar to the one occupied before the move (Webb 2015).

However, due to the dearth of research on the topic, the literature does not provide a clear understanding of the relationship between the motives for migration and the level of structural integration and satisfaction in the labour market. One of the publications addressing the topic is that of Aydemir (2011). Working on the characteristics of immigration towards Canada and using the Longitudinal Survey of Immigrants to Canada - LSIC, the author confirms that the increase in the share of higher-skilled migrants has affected the spouses' skill distribution. Due to the homogamy between both partners, spouses are more qualified than in the past. The immigration of highly skilled workers is associated with the arrival of highly qualified partners. Moreover, the study observes that the overrepresentation of higherskilled immigrants does not necessarily lead to better overall performance in the 
labour market due to the difficulty those migrants have with transferring Canadian human capital acquired abroad. In Australia, Webb (2015) stated, "the migration of highly skilled tertiary-educated people, particularly female partner migrants, is often risky, resulting in disrupted careers, intensification of domestic responsibilities and a re-feminization of health and human service work". According to the author, female migrants face downward occupational mobility and re-orientation. Secondary applicants appear to be more frequently unemployed or partially employed in Australia. A negative effect on job retention among wives (tied migrants) was also observed in the United Kingdom and the United States (Boyle et al. 2001).

Another study using longitudinal data from Canada specifically analysed the link between the motive for migration and the level of integration (CIC 1998). It measured the economic performance of migrants (based on five indicators - level of employment, earnings, incidence of employment earnings, incidence of unemployment insurance benefits and incidence of social assistance payments) for four categories of migrants: principal economic applicants, spouses of economic migrants, immigrants linked to family reunification ${ }^{3}$ and refugees. The authors demonstrate that a good performance in the labour market is observed for the first category. The last two categories show low performance. The spouses and dependents are characterized not only by low income but also by a high risk of unemployment and high rates of social assistance payment.

This relatively poor performance of spouses or family migrants in the labour market is not observed everywhere. For instance, Nekby (2002), studying the employment convergence of immigrants and natives in Sweden using a longitudinal database for the last decade of the twentieth Century and covering 200,000 individuals of whom 19,000 were born abroad, observed "no notable gender differences in employment convergence". These results are in line with those observed in the United States by Blau et al. (2002), who find that "both husbands and wives work and earn less upon arrival than comparable natives, with similar shortfalls for men and women". Furthermore, "both immigrant husbands and wives have similar, positive assimilation profiles in wages and labour supply and eventually overtake both the wages and the labour supply of comparable natives."

The lack of convergence in the literature concerning the position of family migrants in the labour market, particularly in a context of highly skilled migration, justifies further studies. However, an absence of data on the motives for migration hinders such studies. In general, only the administrative reason for migration is available in European statistical data. However, the recorded reason for providing the permit does not always correspond to the actual (subjective) reason. Only through specific surveys can information on the actual motives behind the decision to migrate be obtained and thereby help to clarify the link between the motive(s) and the level of structural integration.

\footnotetext{
${ }^{3}$ This category includes migrants arriving after a family member is already living in Canada.
} 


\subsection{Data and Methods}

The Migration-Mobility Survey 2016, which is described in detail in Chap. 2, was conducted on a population of persons born abroad and with foreign citizenship who have moved to Switzerland in the last 10 years. To be included in the sample population, respondents had to be between 24 and 64 years of age at the time of the survey and at least 18 years of age on their arrival in Switzerland. A total of 5973 people replied to the full questionnaire, either online or by telephone. The survey provides information on the individual's subjective reasons for migration. It also provides information on the existence of an employment contract (job and job offer) in Switzerland at the time of immigration. Based on this information, we construct a typology of reasons for migration, distinguishing between labour-related, familyrelated and other reasons detailed in the next paragraph. Structural integration is assessed using answers to the four questions described below.

\subsubsection{Definition of the Motives to Migrate}

The survey asked for the reasons for migrating to Switzerland. The offered choices included the following: professional reasons, educational and/or study reasons, to start a family, to accompany family member(s), lifestyle reasons, to gain new experience, presence of a social network in Switzerland, tax reasons, political reasons, and other reasons. Respondents were invited to indicate multiple answers, but the survey did not request respondents to rank the answers according to their importance. Professional reasons are the most frequently given reasons to migrate because $61.6 \%$ of the respondents mentioned them. Among the other reasons mentioned, we find lifestyle (19.6\%), gaining new experience (18.8\%), accompanying family $(17.1 \%)$ and starting a family $(12.0 \%)$. Compared with the administrative reasons for migration available from the statistics of foreigners, ${ }^{4}$ the survey underestimates family reasons $(31.3 \%)$ and overestimates professional motives (46.9\%). This divergence is explained by the fact that partners of "professional" migrants are often considered "family-related" migrants by the administration, although their main and self-declared motivation to move to Switzerland is to work. It is understandable that some of the migrants arriving with a family-related administrative permit come to Switzerland with work as the primary motive.

After different attempts at classification, the variable "Reason to immigrate" is defined using five categories:

\footnotetext{
${ }^{4} \mathrm{SEM}$, Statistique sur l'immigration, les étrangers en Suisse. https://www.sem.admin.ch/dam/data/ sem/publiservice/statistik/auslaenderstatistik/monitor/2016/statistik-zuwanderung-2016-12-jahrf.pdf. Accessed 18 June 2016.
} 
- Professional reasons mentioned (including study) but no family reasons, with job or job offer ( $n=2263,69.5 \%{ }^{5}$ men, $30.5 \%$ women $)$

- Professional reasons mentioned (including study) but no family reasons, without job or job offer ( $n=891,57.1 \%$ men, $42.9 \%$ women $)$

- Family reasons mentioned but no professional reason $(\mathrm{n}=1611,28.7 \%$ men, $71.3 \%$ women)

- Both professional and family reasons mentioned $(n=460,46.4 \%$ men, $53.6 \%$ women)

- Only other reasons mentioned ( $\mathrm{n}=748,61.8 \%$ men, $31.2 \%$ women)

\subsubsection{Labour Market Integration}

In the survey, labour market integration was measured according to four indicators that were considered separately: (1) declaring a substantial or slight improvement in the current professional situation, compared with the situation before the move ${ }^{6} ;(2)$ declaring himself currently seeking a job (unemployed); (3) declaring himself currently working under short-term contract or without contract; and (4) not making use of all skills in the current job?. ${ }^{7}$ The choice of indicators is determined by their availability in the survey. The last three indicators are also integrated in the OECD range of indicators of immigrant integration (OECD and European Union 2015).

\subsubsection{Methods}

Descriptive results are displayed to describe the characteristics of the sample according to the reason for migration and gender. In a second part, logistic regressions (binomial and multinomial) are applied on the indicators to assess the effect of the reason for migration on the level of structural integration. Logistic regressions aim at explaining the probability (p) of answering one question (for instance, whether seeking a job) positively in relation to different explanatory variables. The formula is as follows:

\footnotetext{
${ }^{5}$ Weighted proportions.

${ }^{6}$ The question was formulated as follows: "Concerning your professional situation, what would you say overall when comparing your situation today with your situation before moving to Switzerland?"

${ }^{7}$ The question was formulated as follows: "On a scale from 0 (not at all) to 7 (to a very high extent), to what extent are your knowledge and overall skills utilized in your current work? By knowledge and overall skills, we mean your formal education and the skills you obtained while working (onthe-job training)". After considering the distribution of the answers, we considered scores 6 and 7 to indicate a good use of skills, and scores between 0 and 5 to indicate a poor (or no) use of skills.
} 


$$
\operatorname{logit}(p)=\ln \left(\frac{p}{1-p}\right)=\beta_{0}+\beta_{1} x_{i, 1}+\beta_{2} x_{i, 2}+\ldots
$$

with $\beta_{0}$ being a constant and $\beta_{1, \ldots n}$ being the coefficients of the explanatory variables $\mathrm{x} \_(1, \ldots \mathrm{n})$. The exponential value of $\beta_{1, \ldots n}$ represents the odds ratios. A value greater than one indicates an increased risk for a group (for instance women) of being integrated in comparison to the reference group (for instance men, (cf. Cox and Snell (1989)). Confidence intervals at the $95 \%$ limit and significance levels $(* \mathrm{p}<0.05$; $* * \mathrm{p}<0.01 ; * * * \mathrm{p}<0.001)$ are also presented.

To control for possible confounding factors intervening in the relationship between the reason for migration and the level of integration, the models also include different variables suspected of affecting integration, according to the literature mentioned in the previous part of this chapter. The variables introduced in the model are the following:

- Age: less than 30 (reference), 30-39, 40-49, 50 and over

- Gender: male (reference), female

- Year of arrival: 2015-2016 (reference), 2013-2014, 2011-2012, 2009-2010, 2008 and earlier

- Region or country of origin: Germany (reference), Austria, France, Italy, United Kingdom, Spain, Portugal, North America, South America, India, West Africa

- Permit of residence: settlement permit (C) (reference), annual residence permit (B), other (essentially short-term permit (L))

- Current family situation: single without partner, married (including registered partnership, reference), formerly married currently without partner, single or formerly married currently with partner

- Status concerning children: with children (reference), without children

- Level of education: without or Secondary I/II (reference), tertiary

- Having finished studies in Switzerland: no (reference), yes

- Support at the time of immigration: no (reference), yes

- Presence of relatives in Switzerland before migration: no (reference), yes

For indicators referring specifically to the professional outcome (type of contract, use of skills and satisfaction), we retain only occupied persons. We deliberately excluded non-active persons because the indicators do not refer to them. However, we are aware that the sub-group of inactive persons includes migrants who have given up on the idea of entering the labour market due to failure in their quest for a job. The indicator of unemployment refers to active migrant, whether or not occupied. Models are also run on the sub-sample of those arriving for family reasons to identify the sociodemographic factors intervening in the integration of family migrants. 


\subsection{Results}

\subsubsection{Reasons for Migration and Context in Which Migration Occurs}

Table 5.1 presents the distribution of the reasons for immigrating among the currently active population (whether or not occupied) according to some personal characteristics. Active men are more concerned with professional reasons than are women (70\% versus $57 \%$ ), and more than $40 \%$ of them had obtained a work

Table 5.1 Distribution of the reasons to immigrate according to the different characteristics (in \%)

\begin{tabular}{|c|c|c|c|c|c|c|}
\hline & $\begin{array}{l}\text { Profession } \\
\text { with job }\end{array}$ & $\begin{array}{l}\text { Profession } \\
\text { without job }\end{array}$ & Family & $\begin{array}{l}\text { Profession and } \\
\text { family }\end{array}$ & Other & $\begin{array}{l}\text { Sample } \\
\text { size }\end{array}$ \\
\hline \multicolumn{7}{|l|}{ Gender } \\
\hline Male & 42.0 & 20.2 & 11.0 & 8.5 & 18.2 & 1685 \\
\hline Female & 24.8 & 21.5 & 29.8 & 10.7 & 13.3 & 1525 \\
\hline \multicolumn{7}{|l|}{ Level of education } \\
\hline $\begin{array}{l}\text { Secondary } \\
\text { education or less }\end{array}$ & 24.2 & 18.4 & 24.5 & 9.0 & 23.8 & 1349 \\
\hline Tertiary & 43.4 & 23.0 & 15.0 & 10.0 & 8.6 & 1861 \\
\hline \multicolumn{7}{|l|}{ Age } \\
\hline Up to 40 & 35.7 & 17.9 & 20.4 & 7.8 & 18.2 & 1208 \\
\hline $40-64$ & 33.1 & 22.5 & 19.2 & 10.5 & 14.6 & 2002 \\
\hline \multicolumn{7}{|l|}{ Year of arrival } \\
\hline Up to 2011 & 28.5 & 20.8 & 23.2 & 11.8 & 15.6 & 1513 \\
\hline 2012-2016 & 38.8 & 20.8 & 16.6 & 7.5 & 16.3 & 1697 \\
\hline \multicolumn{7}{|l|}{ Country of origin } \\
\hline Germany & 41.9 & 22.8 & 14.5 & 7.3 & 13.5 & 294 \\
\hline Austria & 47.9 & 17.4 & 14.1 & 5.4 & 15.2 & 280 \\
\hline France & 46.9 & 14.7 & 17.3 & 10.0 & 11.1 & 311 \\
\hline Italy & 27.1 & 29.5 & 20.9 & 11.9 & 10.6 & 286 \\
\hline United Kingdom & 54.8 & 9.5 & 18.5 & 6.4 & 10.9 & 274 \\
\hline Spain & 29.5 & 27.1 & 15.3 & 5.8 & 22.5 & 342 \\
\hline Portugal & 20.4 & 20.6 & 18.2 & 13.3 & 27.6 & 349 \\
\hline North America & 34.1 & 12.0 & 34.1 & 13.3 & 6.6 & 272 \\
\hline India & 39.0 & 14.8 & 36.9 & 9.0 & 0.4 & 245 \\
\hline West Africa & 5.4 & 13.6 & 54.7 & 7.1 & 19.2 & 251 \\
\hline South America & 10.8 & 8.8 & 58.4 & 8.9 & 13.1 & 306 \\
\hline Total & 34.1 & 20.8 & 19.6 & 9.5 & 16.0 & 3210 \\
\hline
\end{tabular}

Note: Economically active population only

Source: Migration-Mobility Survey 2016. Weighted results 
contract before migrating. Thirty percent of the women only mention family reasons to explain their arrival in Switzerland (11\% for men). Professional migration is predominant among every group of migrants except for those from South America and West Africa, who are primarily concerned with family migration.

\subsubsection{Integration in the Labour Market: Descriptive Results}

Table 5.2 provides descriptive statistics according to the four selected indicators. For women migrants, we observe a lower level of improvement in integration into the labour market, a higher level of unemployment, a slightly higher level of shortterm contracts and a lower use of skills compared with men. In a country with low unemployment rates and high wages, the fact that almost $20 \%$ of migrants declare not having improved their situation in the labour market after the move most likely reflects the migrants' difficulty in integrating into the labour market, which is more an issue among women than among men.

Table 5.2 also shows that migrants who arrived for professional reasons show better labour market outcomes compared with those who arrived for either family or other reasons. In particular, they declare a better use of skills and an improvement of the situation in the labour market compared with their situation prior to migration. Concerning the improvement of their own professional position, professional

Table 5.2 Description of the indicators of integration into the labour market according to gender, reason to immigrate, and the presence of a job or job offer before migration (in \%)

\begin{tabular}{|c|c|c|c|c|c|c|c|c|}
\hline & \multicolumn{2}{|c|}{ Gender } & \multicolumn{5}{|l|}{ Reason } & \multirow{2}{*}{$\frac{\mathrm{N}}{\text { Total }^{\mathrm{c}}}$} \\
\hline & Male & Female & Prof. w job & Prof. w/o job & Family & Prof. and family & Other & \\
\hline \multicolumn{9}{|c|}{ Substantial or slight improvement in the labour market ${ }^{\mathrm{a}}$} \\
\hline Yes & 83.5 & 75.9 & 84.3 & 85.6 & 66.7 & 83.4 & 76.4 & 2125 \\
\hline No & 16.5 & 24.1 & 15.7 & 14.4 & 33.3 & 16.6 & 23.6 & 600 \\
\hline \multicolumn{9}{|c|}{ Currently unemployed } \\
\hline Yes & 2.5 & 6.9 & 2.1 & 6.1 & 6.3 & 3.2 & 6.2 & 147 \\
\hline No & 97.5 & 93.1 & 97.9 & 93.9 & 93.7 & 96.8 & 93.8 & 3063 \\
\hline \multicolumn{9}{|c|}{ Work contract of limited duration/no contract ${ }^{\mathrm{a} / \mathrm{b}}$} \\
\hline Yes & 13.6 & 17.4 & 12.3 & 20.3 & 13.0 & 18.0 & 16.6 & 446 \\
\hline No & 86.4 & 82.6 & 87.7 & 79.7 & 87.0 & 82.0 & 83.4 & 1992 \\
\hline \multicolumn{9}{|c|}{ Utilization of skills from 0 (not at all) to 7 (to a very high extent) ${ }^{\mathrm{a}}$} \\
\hline $0-5$ & 39.2 & 46.2 & 33.2 & 41.8 & 57.5 & 38.6 & 48.6 & 1149 \\
\hline $6-7$ & 60.8 & 53.8 & 66.8 & 58.2 & 42.5 & 61.4 & 51.4 & 1573 \\
\hline Total & 100 & 100 & 100 & 100 & 100 & 100 & 100 & 3210 \\
\hline
\end{tabular}

Note: ${ }^{a}$ Economically active population only, also excluding migrants seeking a job. ${ }^{\mathrm{b}}$ After the

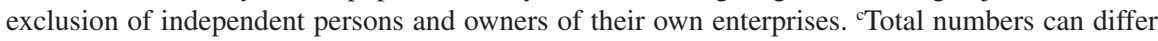
according to the indicator due to the definition of the population (for example, economically active or occupied) and missing values

Source: Migration-Mobility Survey 2016. Weighted results 
migrants who had arrived without a contract are slightly more satisfied than are those who arrived with a job or a job offer. Because of the relatively low level of unemployment in the country, the proportion of persons seeking a job is low for every group. However, this proportion is the highest among migrants who arrived for professional reasons without a work contract, for family reasons only or for other reasons.

Overall, approximately $85 \%$ of active migrants have a permanent contract. A higher proportion of those who arrived for professional reasons but without a job at the time of the move also have a job with a short-term contract/without a work contract compared with migrants who arrived for other reasons (including family reasons).

\subsubsection{Relationship Between Reason for Migration and Labour Market Performance. Results of Logistic Regressions}

After considering the confounding factors, the logistic regressions show that the reason to migrate is strongly associated with the level of improvement in the labour market following migration, the risk of unemployment, and the extent to which previously acquired skills are used but not with the type of contract.

In more detail, migrants who have arrived for family reasons or for other reasons have a smaller probability of improving their work conditions following migration than do migrants who arrived for professional reasons with a work contract (O.R. $0.46 * * *$ and $0.61 * *$, respectively, Table 5.3). Migrants who arrived in Switzerland for both professional and family reasons do not present any significant variation concerning work conditions compared with those whose migration is only motivated by professional reasons. As expected, the results confirm that migrants who arrived for family reasons can more frequently encounter difficulties finding work that matches their personal aspirations. Interestingly, among professional migrants, having a contract at the time of arrival does not ensure the highest level of satisfaction. The interpretation of this result must consider the fact that the labour market functions better in Switzerland than in most of the countries of origin, having a wide range of professional opportunities and high wages. However, despite the relatively favourable situation, acceptable employment in the labour market is not ensured for every group of migrants, in particular for family or migrants who arrived for nonprofessional reasons.

Compared with the reference group, economically active migrants who arrived for family reasons (O.R. 2.21*) or for other reasons (O.R. 1.40**) more frequently state that their knowledge and skills are poorly used in their current work. Such results are in line with the hypothesis that family migrants face difficulties with integrating into the labour market in a position that corresponds to their skills. Among migrants who arrived in Switzerland for professional reasons, the risk of not adequately using their skills is higher among those without a job or job offer at the 


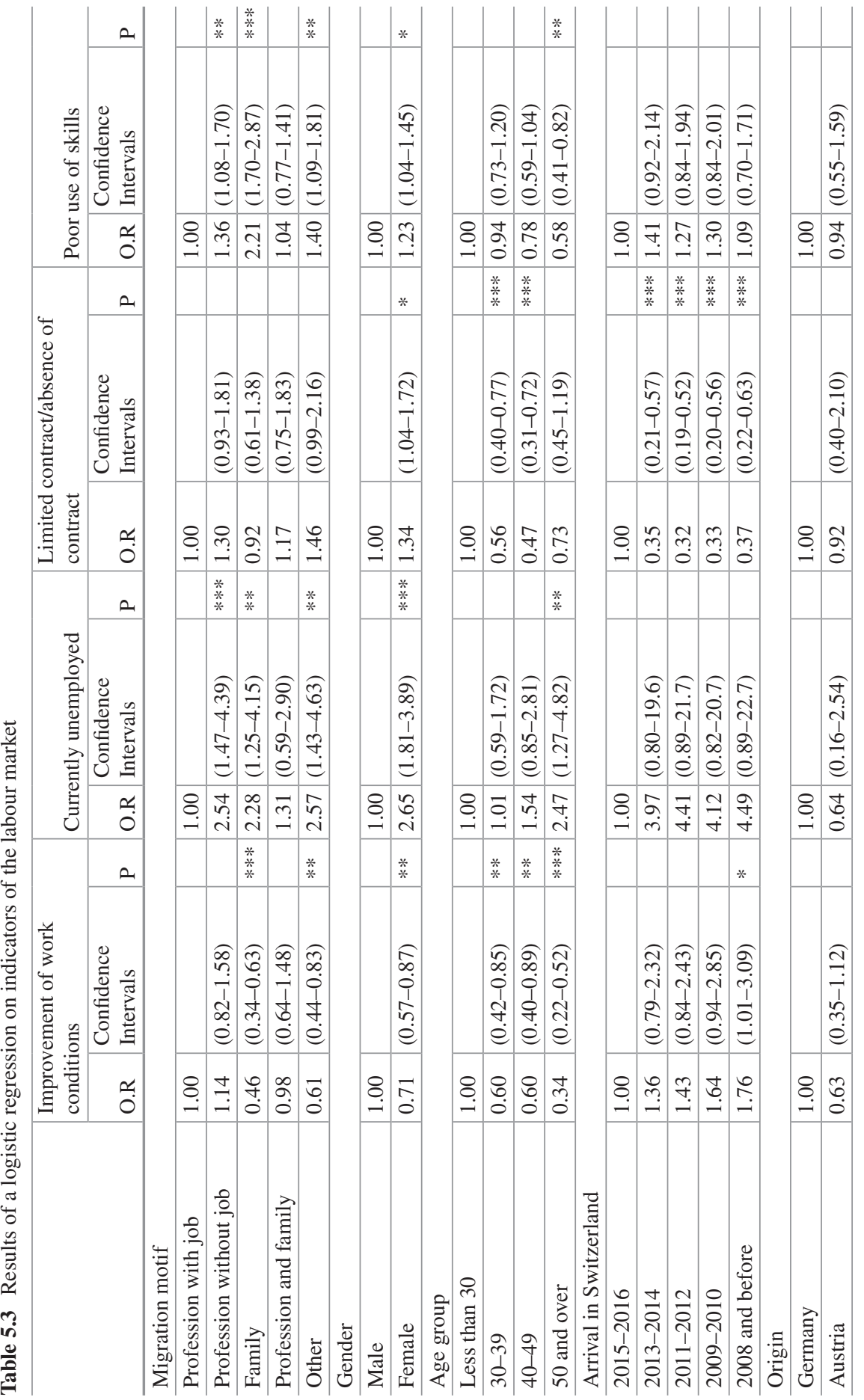




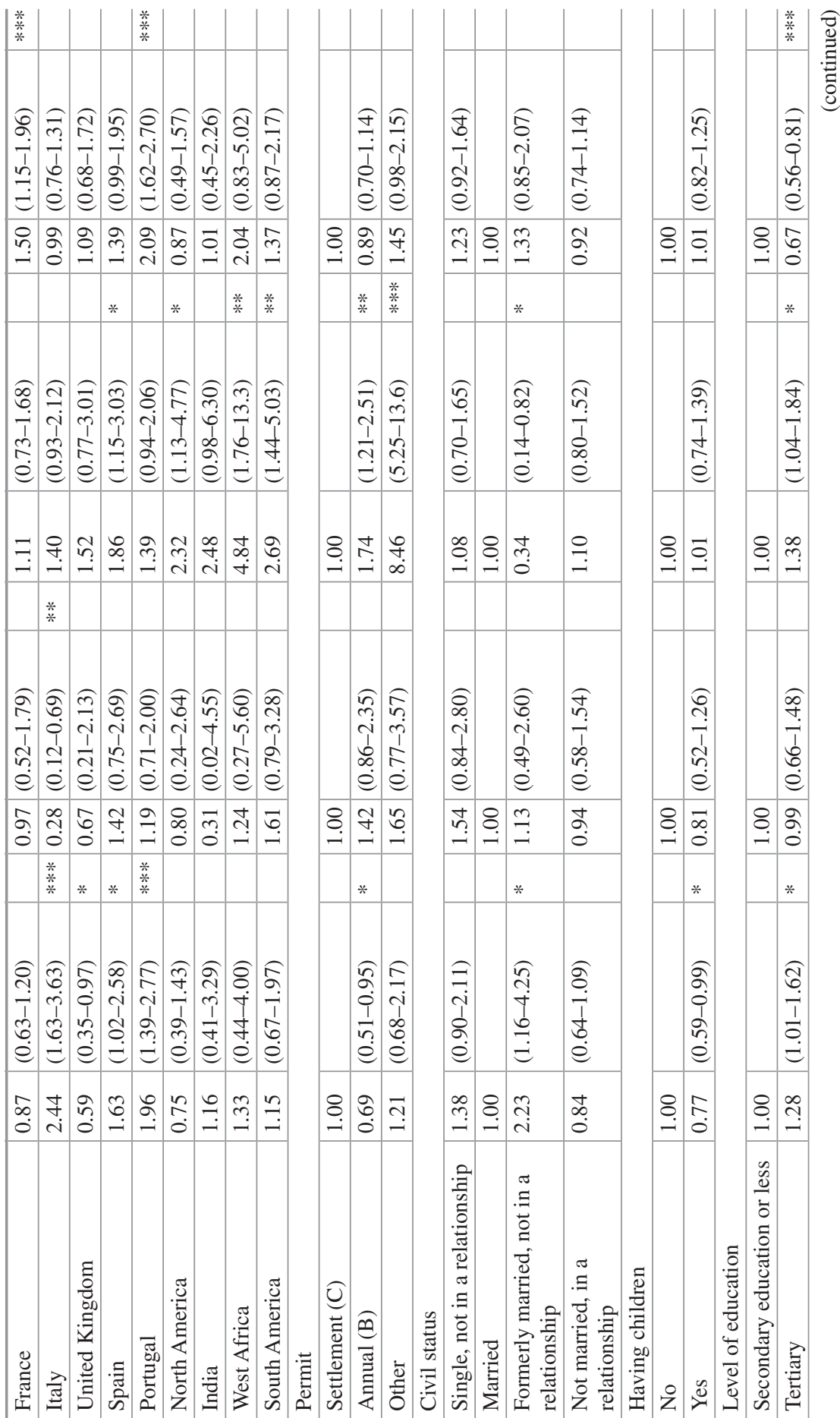




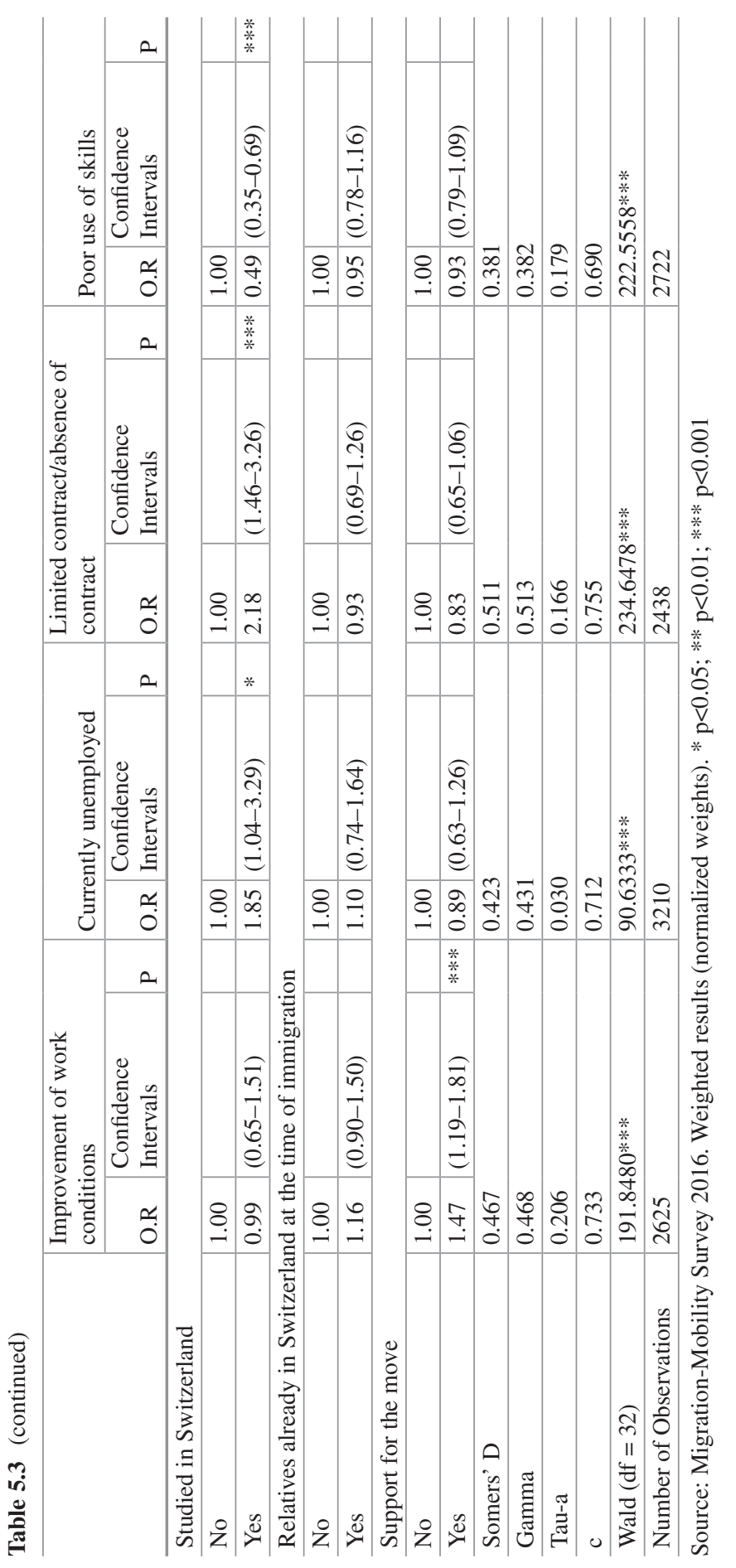


time of migration compared with those with a job (O.R. 1.36**), suggesting that if job opportunities exist for this category of migrants, there is a risk of skills mismatch.

The labour market in Switzerland privileges permanent contracts in many sectors. Those with short-term contracts are primarily the academic sector, some international organizations and sectors with primarily seasonal activities. These sectors hire a high proportion of migrants; hence, the reason why short-term contracts are more frequent among migrants than among natives. ${ }^{8}$ The reason for migration does not significantly influence the probability of having a short-term contract.

As expected, the risk of having to seek a job is higher for all groups (except for those who arrived for both professional and family reasons) compared with migrants arriving with a job contract. It is highest among those who arrived for professional reasons but without a job (O.R. 2.54**) or for other reasons (O.R. 2.57**).

Significant differences are then observed between migrants arriving for professional reasons without a job contract and those having secured a contract before the migration, the former being systematically in a less favourable position. This situation can be explained by the fact that migrants arriving with a contract had the prior possibility to choose whether to migrate based on knowing what type of job they would have in Switzerland. The decision to move is therefore made based on the position that is offered. Those arriving without a job have no prior information concerning a potential future job and therefore are not able to make such an informed choice.

In addition to the effect of the reason to migrate, the model also shows the effect of different sociodemographic characteristics on the level of integration. Compared with men, and after considering the other confounding factors, women have a lower probability of improving their position in the labour market through the migration and a slightly higher probability of not using their skills adequately and of having a limited contract. They are also significantly more concerned by being unemployed. These results confirm those based on the descriptive analysis (Table 5.2) and suggest that even after considering the role of the reason for migration, women are disadvantaged on the labour market compared with men. Compared with migrants aged less than 30, older migrants present a lower probability of declaring an improvement of their work conditions. However, they also present a lower risk of poorly using their skills and a lower risk of having a short-term contract. Younger migrants thus appear more frequently satisfied with their work conditions, although they have not yet been able to find a job that matches their skills. This situation can be partially explained by the expectations of those young migrants towards ascending professional mobility, which make them consider their current position a temporary state (cf. theory of career mobility (Sicherman and Galor 1990)). Migrants who arrived in 2008 or before also show an increased probability of declaring having

\footnotetext{
${ }^{8}$ According to the Swiss Federal Statistical Office, the proportion of workers with contracts of limited duration is $8 \%$ among Swiss citizens and $11.3 \%$ among foreigners (Swiss Federal Statistical Office, Swiss Labour Force Survey, https://www.bfs.admin.ch/bfs/en/home/statistics/cataloguesdatabases.assetdetail.je-f-03.02.01.23.html. Accessed 5 June 2018).
} 
improved their working conditions compared with those who arrived in the last 2 years. Recent migrants also present a higher risk of having a short-term contract.

Concerning the country/region of origin, non-European migrants present the highest probability of having contracts of limited duration. Southern Europeans more frequently declare having improved their situation on the labour market. Those concerned foremost by underuse of skills are Portuguese and French. There is therefore a paradox concerning the Portuguese migrants who declare an improvement in their professional position although their skills are underused. This paradox is most likely explained by the fact that such migrants generally come from a country with low professional opportunities at the time of their migration and then find better working conditions in Switzerland although they do not use all of their professional skills.

Results concerning the permit of residence and civil status are rarely significant, meaning that these dimensions do not affect the integration on the labour market. The only significant results refer first to a small decrease in the probability of having improved their professional situation among holders of annual resident permits (B permit) and second to a significant increase in the risk of a short-term contract among the groups with a B permit (O.R. 1.74**) or other permit (short-term permit (L permit) in general, O.R. 8.46***).

As far as the level of education is concerned, one can observe a lower risk of not using the acquired skills (O.R. 0.67***) and a higher improvement of the work conditions (O.R. 1.28*) for tertiary-educated migrants compared with others. Those who studied in Switzerland present a slightly higher level of unemployment (O.R. $1.85^{*}$ ) and a low level of underuse of skills (O.R. 0.49***), confirming the results of Akresh (2006) for the United States. The presence of a relative in Switzerland prior to the migration and being a parent do not significantly affect the indicators. Finally, those having received support for the move declare a higher level of satisfaction (O.R. 1.47***) compared with those not having had such support. In general, all of the results are in line with what would be expected.

\subsection{Conclusions}

This paper aims at providing a better understanding of the extent to which the reason to migrate affects current migrants' situation on the labour market (the so-called structural integration), as measured by different indicators. Based on the MigrationMobility Survey, this study assesses the relationship between reason to migrate and integration. Among the 6000 respondents 3210 are active on the labour market. The question referring to the reason to migrate, which is included in the survey, also provides the self-declared rather than the administrative reason, the latter being the information that is generally available in national statistics.

Descriptive results show that gender and the existence of a work contract or job offer prior to migration significantly influence the reason to migrate. Compared with men, women arrive more frequently in Switzerland for family reasons, often 
after the arrival of their partner, and generally without a work contract. Conversely, most male migrants move to Switzerland for professional reasons, and almost half already have a work contract prior to arrival, meaning that for one of two male migrants, the move to Switzerland is prepared and anticipated. The existence of a contract is most frequent among highly educated migrants and among those coming from neighbouring countries and is least frequent among West African and South American migrants. One of the results of our analyses is the diversity of situation according to origin, particularly differences between migrants from Southern Europe and Western Europe and between migrants from the Southern Continents (West Africa and South America) and from industrialized countries.

Overall, migrants consider themselves relatively well integrated in the labour market: in particular, three-quarters of the men and almost two-thirds of the women declare an improvement in their work conditions after migration, their unemployment rate is low, fewer than $20 \%$ of migrants have short-term contract or work without a contract, and approximately $60 \%$ use their skills at work. Such results are not surprising given the favourable state of the Swiss labour market and the characteristics of newcomers. The results are in line with those presented by the OECD and European Union (2015) for comparable indicators and translate to a rather good working situation for migrants in Switzerland compared with other countries. However, after considering confounding factors using a logistic regression, one can observe differences in the level of integration according to the reason for migration. Not only family migrants but also migrants who arrived in Switzerland for other reasons present a lower probability of job satisfaction and a higher risk of underuse of skills compared with those arriving with a work contract. Significant differences are also observed between professional migrants with or without a work contract, the latter facing more difficulties, according to all of our indicators (in particular concerning the use of skills and the probability to be unemployed), with integrating into the labour market in a good position.

Results are in line with those of the rare studies mentioned before, particularly in North America (CIC 1998), which have explored the relationship between reasons for migrating and labour force outcomes. The results contradict the few studies that specifically use professional wages as an indicator of integration (Nekby 2002). However, due to the lack of data, we were not able to investigate income as an indicator of structural integration. Overall, the results confirm that tied or family migrants, often the woman in a partnership, face more difficulties than men do with entering the labour market and obtaining a job corresponding to their skills and that satisfies them.

The subjective evaluation of migrants' position in the labour market, particularly in terms of the level of satisfaction and improvement in their conditions following migration, depends upon both their current position and that preceding migration. Some groups of migrants, particularly those from Portugal, do not use all their skills at work, which can diminish their remuneration and lead to frustrations; however, they declare an improvement in their situation. This paradox can be explained by the poor working conditions before migration in the period following the 2008 financial crisis. The absence of professional prospects in the country of origin can lead them 
to positively evaluate their current situation, although this evaluation would not always objectively be positive. Reflecting more widely, one can suggest that the self-estimated situation on the labour market post-migration also depends upon previous experiences and not only upon the current situation.

Results obtained can contribute in at least two ways to the debate on migration and integration policies, at least in Switzerland if not also in European countries.

First, results highlight the importance of the motive for migration in influencing the position migrants have in the labour force. Those who have migrated for family reasons, particularly women, and those arriving from non-European countries are particularly concerned by lower work conditions. Such a result justifies specific integration policies for non-professional migrants, tied migrants ${ }^{9}$ in particular. It also raises concerns regarding how women can be better integrated into the labour market. The difficulty for migrants to integrate into the labour market in a position that corresponds to their skills not only leads to a waste of competences in the labour market (brain waste) but also can result in personal dissatisfaction with the move to the recipient country. Further analyses, which are not presented here, show that family migrants, particularly women, declare a lower level of satisfaction concerning the move compared with migrants who have moved for professional reasons.

Second, the analyses conducted among family migrants demonstrate the importance of gender in professional outcomes. The results clearly demonstrate that when the family migrant is a man, he is more frequently able to obtain a professional position leading to an improvement in his working conditions (compared with his situation before migration) compared with a woman. This result clearly raises the issue of gender equality in the labour market.

\section{References}

Adsera, A., \& Chiswick, B. R. (2007). Are there gender and country of origin differences in immigrant labor market outcomes across European destinations? Journal of Population Economics, 20(495), 1432-1475. https://doi.org/10.1007/s00148-006-0082-y.

Akresh, I. R. (2006). Occupational mobility among legal immigrants to the United States. International Migration Review, 40(4), 854-884.

Akresh, I. R. (2008). Occupational trajectories of legal US immigrants: Downgrading and recovery. Population and Development Review, 34(3), 435-456. https://doi. org/10.1111/j.1728-4457.2008.00231.x.

\footnotetext{
${ }^{9}$ In the largest cities of Switzerland, initiatives already exist to try to integrate tied, family or female migrants into the labour market. Generally, those initiatives are private, occasionally with public subsidies and focussed on highly skilled tied migrants.
} 
Amuedo-Dorantes, C., \& De la Rica, S. (2007). Labour market assimilation of recent immigrants in Spain. British Journal of Industrial Relations, 45(2), 257-284. https://doi.org/10.111 1/j.1467-8543.2007.00614.

Aydemir, A. (2011). Immigrant selection and short-term labor market outcomes by visa category. Journal of Population Economics, 24(2), 451-475. https://doi.org/10.1007/s00148-009-0285-0.

Bevelander, P., \& Pendakur, R. (2014). The labour market integration of refugee and family reunion immigrants: A comparison of outcomes in Canada and Sweden. Journal of Ethnic and Migration Studies, 40(5), 689-709.

Blau, F. D., Kahn, L. M., Moriarty, J. Y., \& Souza, A. P. (2002). The role of the family in immigrants' labor-market activity: evidence from the United States. Cambridge: National Bureau of Economic Research.

Blau, F. D., Kahn, L. M., \& Papps, K. L. (2011). Gender, source country characteristics, and labor market assimilation among immigrants. The Review of Economics and Statistics, 93(1), 43-58. https://doi.org/10.1162/REST_a_00064.

Boyle, P., Cooke, T. J., Halfacree, K., \& Smith, D. (2001). A cross-national comparison of the impact of family migration on women's employment status. Demography, 38(2), 201-213.

CIC. (1998). The economic performance of immigrants: immigration category perspective (citizenship and immigration Canada). Ottawa: IMDB Profile Series.

Cooke, T. J. (2013). All tied up: Tied staying and tied migration within the United States, 1997 to 2007. Demographic Research, 29, 817-836.

Cox, D. R., \& Snell, E. J. (1989). Analysis of binary data. In Monographs on statistics and applied probability (Vol. 32). London: Chapman and Hall.

DeVoretz, D. J., Pivnenko, S., \& Beiser, M. (2004). The economic experiences of refugees in Canada. Bonn: IZA Discussion Paper No. 1088.

Dustmann, C., \& Fabbri, F. (2003). Language proficiency and labour market performance of immigrants in the UK. The Economic Journal, 113(489), 695-717. https://doi.org/10.1111/14680297.t01-1-00151.

Fibbi, R., Lerch, M., \& Wanner, P. (2006). Unemployment and discrimination against youth of immigrant origin in Switzerland: When the name makes the difference. Journal of International Migration and Integration, 7(3), 351-366.

Harbison, S. F. (1981). Family structure and family strategy in migration decision making. In G. F. De Jong \& R. W. Gardner (Eds.), Migration decision making. Multidisciplinary approaches to microlevel studies in developed and developing countries (pp. 225-251). New York: Pergamon Press.

Kofman, E. (2004). Family-related migration: A critical review of European Studies. Journal of Ethnic and Migration Studies, 30(2), 243-262. https://doi.org/10.1080/13691830420002006 87.

Kofman, E., \& Raghuram, P. (2005). Gender and skilled migrants: Into and beyond the work place. Geoforum, 36(2), 149-154. https://doi.org/10.1016/j.geoforum.2004.06.001.

Liebig, T., Kohls, S., \& Krause, K. (2012). The labour market integration of immigrants and their children in Switzerland. Paris: OECD Social, Employment, and Migration Working Papers No 128.

Luthra, R. R., Platt, L., \& Salamońska, J. (2014). Migrant diversity, migration motivations and early integration: The case of poles in Germany, the Netherlands, London and Dublin. University College London, Department of Economics, CReAM Discussion Paper Series, 12/14.

Mahroum, S. (2000). Highly skilled globetrotters: Mapping the international migration of human capital. $R \& D$ Management, 30(1), 23-32.

Man, G. (2004). Gender, work and migration: Deskilling Chinese immigrant women in Canada. Women's Studies International Forum, 27(2), 135-148.

Meares, C. (2010). A fine balance: Women, work and skilled migration. Women's Studies International Forum, 33(5), 473-481.

Nauck, B., \& Settles, B. H. (2001). Immigrant and ethnic minority families: An introduction. Journal of Comparative Family Studies, 32(4), 461-463. 
Nekby, L. (2002). How long does it take to integrate? Employment convergence of immigrants and natives in Sweden. Stockholm, FIEV Working Papers Series, 185.

OECD \& European Union. (2015). Indicators of immigrant integration 2015: Settling in. Paris: OECD Publishing. https://doi.org/10.1787/9789264234024-en.

Rashid, S. (2009). Internal migration and income of immigrant families. Journal of Immigrant \& Refugee Studies, 7(2), 180-200.

Sicherman, N., \& Galor, O. (1990). A theory of career mobility. Journal of Political Economy, 98(1), 169-192.

Stark, O. (1991). The migration of labor. Cambridge: Basil Blackwell.

Wanner, P., Zufferey, J., \& Fioretta, J. (2016). The impact of migratory flows on the Swiss labour market. A comparison between in-and outflows. Migration Letters, 13(3), 411-426.

Webb, S. (2015). The feminisation of migration and the migrants VET policy neglects: The case of skilled women secondary migrants in Australia. Journal of Vocational Education \& Training, 67(1), 26-46.

Open Access This chapter is licensed under the terms of the Creative Commons Attribution 4.0 International License (http://creativecommons.org/licenses/by/4.0/), which permits use, sharing, adaptation, distribution and reproduction in any medium or format, as long as you give appropriate credit to the original author(s) and the source, provide a link to the Creative Commons licence and indicate if changes were made.

The images or other third party material in this chapter are included in the chapter's Creative Commons licence, unless indicated otherwise in a credit line to the material. If material is not included in the chapter's Creative Commons licence and your intended use is not permitted by statutory regulation or exceeds the permitted use, you will need to obtain permission directly from the copyright holder.

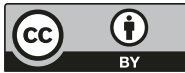

